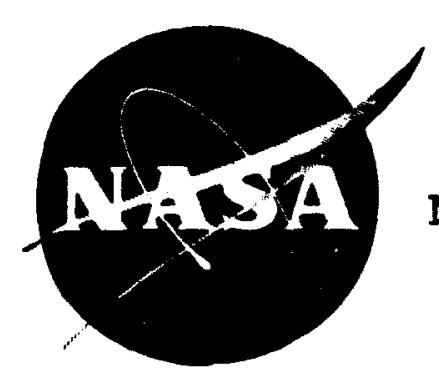

NASA TM X-58002

\title{
STATUS OF LUBRICANTS FOR MANNED SPACECRAFT
}

\author{
Frans G. A. de Laat \\ TRW Systems \\ Redondo Beach, California \\ R. V. Shelton \\ North American Aviation, Inc. \\ Downey, California \\ J. H. Kimzey . \\ Manned Spacecraft Center \\ Houston, Texas
}

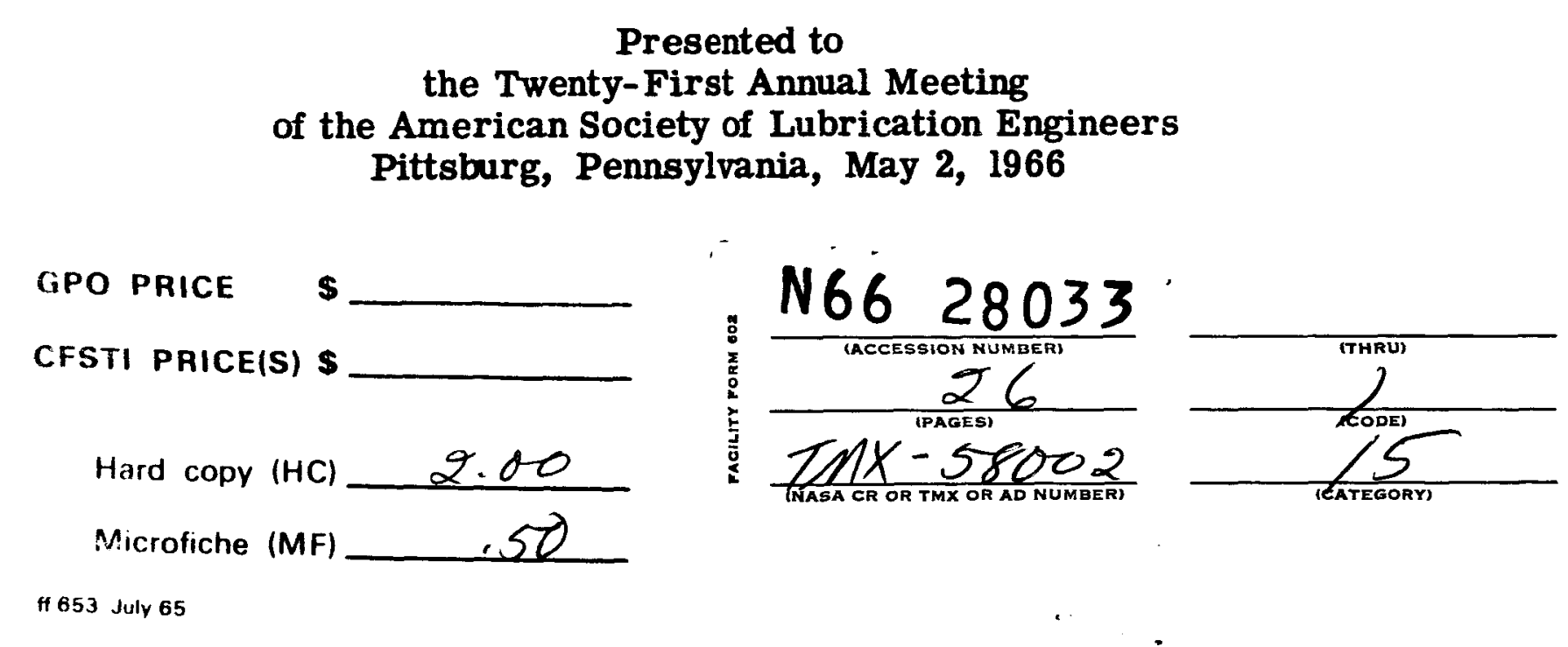

NATIONAL AERONAUTICS AND SPACE ADMINISTRATION

June 1966 
STATUS OF LUBRICANTS FOR MANNED SPACECRAFT

By Frans G. A. de Laat, ${ }^{1}$ R. V. Shelton, ${ }^{2}$ and J. H. Kimzey ${ }^{3}$ ABSTRACT

This paper reports the status of lubricants selected for use on manned spacecraft such as Apollo. The selection of lubricants was based on four major test programs: lubricant compatibility with oxygen-rich environment for crew-campartment toxicity-order hazard evaluations; lubricant-propellant compatibility investigations for long-exposure endurance; solid-dry-film lubricant compatibility with various anodic coatings; and studies of lubricant sliding-friction behavior in vacuums such as are encountered in space.

These tests resulted in the selection of several solid-dry-film lubricants, such as a completely inorganic, electrophoretic, bonded material containing molybdenum disulfide, graphite, and lead sulfide as the major Iubricity constituents. Besides successfully passing the oxygen-campatibility test, this lubricant also exhibited unusually low friction coefficients on sulfuric anodized aluminum substrates, as well as in vacuum or in atmospheric conditions.

Among the greases, a completely polymeric perfluorinated material with a fluorocarbon-telomer thickener showed an unsurpassed compatibility with propellants and, in the oxygen-compatibility tests, a remarkable inertness.

\footnotetext{
$I_{\text {TRW Systems, Redondo Beach, California. }}$

${ }^{2}$ Space and Information Systems Division, North American Aviation, Inc., Downey, California.

${ }^{3}$ Structures and Mechanics Division, NASA Manned Spacecraft Center, Houston, Texas.
} 
INTRODUCTION

Any attempt to compile a report on the status of lubricants and lubrication in Project Apollo is difficult for many reasons. First, the designs of many Apollo systems and subsystems are not frozen. Second, many areas involve a large number of subcontractors. Third, the prinary concern in spacecraft mechanisms was focused on generally satisfactory operation, thereby taking into consideration only severe weight and configuration constraints; consequently, inadequate attention was given to the environmental effects on moving parts, in general, and on the lubricants themselves in particular. REQUIREMENTS FOR A LUBRICANT USED IN SPACE

A lubricant to be used in space must meet many requirements, including the following:

(a) It must not evaporate or degrade.

(b) It must not contaminate liquids or gases.

(c) It must not react with solids, liquids, or gases which it might contact.

(d) It must not have migratory-creep tendencies, especially under zerogravity conditions.

(e) It must not be a toxicity or flammability hazard.

(f) It must not inhibit electrical or thermal activities, or pramote undesirable ones.

(B) Most important of all, it must provide low friction coefficients while carrying heavy loads in the space environment. ENVIRONMENTAL CONDITIONS

\section{Vacuum}

The absolute pressure outside the earth's atmosphere is estimated to be approximately $10^{-13}$ torr (mm $\mathrm{Hg}$ ), and in interstellar space, approximately $10^{-16}$ torr. Exact duplication of these pressures is extremely difficult, if 
not impossible. The best laboratory vacuum obtainable in systems containing lubricant test specimens is between $10^{-8}$ and $10^{-10}$ torr.

Temperature

Liquid oxygen at $-297.3 \mathrm{~F}$ is the low temperature extreme. Other low temperatures, resulting fram permanent shadow regions, are estimated to be between $-100 \mathrm{~F}$ and $-250 \mathrm{~F}$.

Except for the launch and reentry, no major difficulties caused by high temperatures are anticipated. During launch and reentry, temperatures in the affecten wieas should not reach more than $550 \mathrm{~F}$, and this temperature should not be maintained for more than a short period.

Vibration

While the vibration spectrum which spacecraft camponents must withstand is necessarily broad, the highest vibration levels are experienced only in those areas where lubrication is not required, such as the outer shell of the service module or the forward heat shield of the command module.

\section{Zero Gravity}

Increased surface tension may cause liquid lubricants, because of migratory creep, to coat housings and other areas which do not require lubrication. As a result, the moving parts would lose either their liquid coatings or the benefit of circulation which would clean, cool, and replenish wear surfaces with fresh lubricant. Also, the motion of parts requiring lubrication will tend to create voids in critical areas. A small amount of lubricant may remain in contact with the surfaces, while most of the lubricant will remain at a distance and not be used.

\section{Radiation}

Direct radiation exposure will be limited to exterior surfaces such as the docking parts, lunar landing gear, and antennas. The few rubbing or moving 
parts directiy exposed to radiation are all lubricated with radiation-resistant solid-dry-film Iubricants. Most other mechanisms are shielded sufficiently . to eliminate possible lubricant degradation.

\section{General Considerations}

The effects of corrosion on lubricants vary. Solid-dry-film lubricants containing molybdenum disulfide and, in some instances, graphite are unsatisfactory in high humidities which exist during prelaunch periods. Also, fluorocarbon greases such as unsaturated polychlorotrifluoroethylenes, when combined with air and moisture, can become acidic and corrosive, particularly to steel. Chlorofluorocarbon greases, however, are usually inert, do not contain hydrogen, and, therefore, are quite corrosion resistant, especially the perchlorofluorocarbon types (1). On the other hand, greases containing corrosion inhibitors may react with solid-dry-film lubricants.

The absence of moisture in a vacuum causes graphite, when used alone, to be more of an abrasive than a lubricant (2). However, as an ingredient in soliddry-film-lubricant formulations, graphite appears satisfáctory for use in vacuums.

The little available data on propellant- and gaseous oxygen-compatibility studies with lubricants are not suitable for extrapolation. For example, the cabin atmosphere at 60-90 F and 5 psia might contain $92.76 \%$ oxygen, $2.94 \%$ carbon dioxide, and 4.30\% water vapor; corrosion rates for metals in such environments are not known, either singly or in combination with lubricants. The slightly acid condition could be much more severe in the absence of nitrogen, since nitrogen in air may be a natural inhibitor. TYPES OF LUBRICANTS

Considering the range of environments, many kinds of lubricants are available for Apollo spacecraft. 
Oils are restricted to use in shock struts of the docking hardware (in the . form of hydraulic fluids) and in sealed high-speed precision bearings in tape recorders and cameras.

\section{Greases}

Greases will be used in gear boxes and sealed bearings, as well as on fittings, linkages, cables, pistons in pyrotechnic devices, guillotine cutters, O-rings, and valve seats. Lithium soap or fluorocarbon telomers are typical thickeners, with the base fluid being a silicone, a fluorinated hydrocarbon, or a fluorocarbon.

\section{Solid-Dry-Film Lubricants}

The solid-dry-film lubricants are considered primarily for sliding friction in thermal-vacuum areas, including threads on fasteners, gears, and sprockets.

Binders vary from inorganic materials to special organic resins, and lubricity constituents include PTFE, graphite, molybdenum disulfide, lead sulfide, silver, tin, indium, and bismuth. Typical thicknesses vary from*0.0003 to 0.0005 inches. Coatings can be applied to metallic as well as non-metallic substrates, including glass, elastomers, and rubbers. Cleaning and preparation of the base material is critical; to obtain optimum results, experience is requirea.

\section{Composite Lubricants}

Composite lubricants are intended for use on bushings', sleeves, or retainers for rolling-friction bearings. They consist of a wide range of polymeric materials, such as PTFE and aromatic polymides, and others that are largely metallic. Silver, gold, copper, lead, tin, bronze, and aluminum have been 
used in quantities as high as $70 \%$. Molybdenum disulfide is a typical Iubricant additive, but selenides, graphite, and mica are also used. Fillers include ceramics, fiber glass (both woven threads and randomly dispersed fibers), and various synthetic fibers. CREW-COMPARTMENT ENVIRONMENT-COMPATIBILITY TESTS

Some lubricants may produce excessive quantities of toxic or objectionable products under oxygen exposure at mildly elevated temperatures. Flammability of lubricants exposed to pure oxygen is also a recognized hazard. For those lubricants considered for use in the Apollo crew compartment, crew safety considerations require data regarding lubricant oxygen-gassing products for evaluations of the toxicity-odor hazards. A test procedure was established to determine the weight loss of candidate lubricants and the concentration and identification of oxygen-gassing products after exposure to a 5-psia, $99.9 \%$ oxygen-rich environment at $200 \mathrm{~F}$ for a 72 -hour period. The odor of the gassing atmosphere, the rocm-temperature condensation rate, and the presence of organic materials in the condensate were also measured.

The most important part of the test setup consisted of a gas chramatograph system for the detection of carbon monoxide, carbon dioxide, and water. The total organic content of the vapor, as well as of the condensate of each lubricant, was determined by the gas chromatograph hydrogen-flame ionization detector. An osmometer-type olfactameter was used for odor measurements, with ratings of detectable, objectionable, and irritating. Detectable was defined as any odor detected by the olfactory sense but not necessarily objectionable or inflammatory. Objectionable was, in this case, an unpleasant or nauseating odor, such as odors of putrid materials and chain mercaptans. Irritating odors were those which produce a burning or astringent effect on 
eyes, or nasal or oral surfaces; examples of irritants are alpha-bromoacetone, hydrogen chloride, and sodium hydride dust.

During the test program, the conditịons were altered from the 72-hour exposure period at $200 \mathrm{~F}$ to 336-hour exposure at $155 \mathrm{~F}$, which more closely simulated the 14-day Apollo mission and thereby maintained a reasonable data correlation.

Interpretation of toxicological and histopathological observations is extremely difficult and not well understood. Also, sealing techniques and quantities of candidate lubricants were influential factors. Consequently, no rigid test parameters were imposed, except for the following general guidelines: a maximum of 100 parts per million total organic components; no irritating odor; and a close observation of carbon monoxide in parts per million.

Table 1 identifies the lubricants tested and reported. The test equipment schematic is shown in Fig. I, and the weight loss, oxygen-gassing products, odor, and condensate of various lubricants are shown in Table 2. LUBRICANT COMPATIBILITY WITH SPACECRAFT PROPELIANTS

The selection of lubricants compatible with Apollo propellant materials presented a special problem. Extensive work performed by Messina and Gisser $(2,3)$ cisarly indicated that virtually all conventional oils and greases (petroleums, dicarboxylic acid esters, silicates, silicones, and polyglycols) are either miscible, reactive, and/or explosive under medium-impact energy levels. A few oils and greases were not sensitive to impact with liquid oxygen at 68-foot-pound levels. Static exposure tests conducted with these Iubricants in $\mathrm{N}_{2} \mathrm{H}_{4}$ (hydrazine) fuel for 24 hours, both in the liquid and vapor phase, and in $\mathrm{N}_{2} \mathrm{O}_{4}$ (nitrogen tetroxide) oxidizer, 1 hour in liquid and 24 hours in vapor phase, revealed excessive solubility and, in some 
instances, reaction (4) (Table 3). Greases applied to stainless steel panels and submerged in the propellant at room temperature were evaluated for solu- . bility rate, color change, and bubbling or gas formation. The results of these tests were disappointing.

Most solid-dry-film lubricants are equally undesirable for use on components submerged in fuels, such as $50 \% \mathrm{~N}_{2} \mathrm{H}_{4}+50 \% \mathrm{UDMH}$ (unsymmetrical dimethylhydrazine) and monamethylhydrazine, or in oxidizers, such as $\mathrm{N}_{2} \mathrm{O}_{4}$ and Iiquid oxygen. Molybdenum disulfide, a major lubricity constituent of solid-dry-film lubricants, has a catalytic effect on hydrazine fuels and causes severe corrosion on all common metals when in contact with $\mathrm{N}_{2} \mathrm{O}_{4}$.

At this point, it was evident that the available information was limited and not suitable for spacecraft applications. Moreover, most of these data were derived from limited and short-exposure immersion tests, that is, 1 to 24 hours. A long-exposure lubricant-propellant compatibility test program was initiated for Project Apollo. Candidate lubricants were submerged in $50 \% \mathrm{~N}_{2} \mathrm{H}_{4}+50 \%$ UDMH per MII-P-27402, monamethylhydrazine (MMH) per MII-P-27404, and nitrogen tetroxide $\left(\mathrm{N}_{2} \mathrm{O}_{4}\right)$ per MII-P-26539. The greases were sandwiched between two panels of 321 stainless steel, while the solid-dry-film lubricants were coated on only one side of the panel and burnished. Apollo specifications required a 2l-day immersion test either in $\mathrm{N}_{2} \mathrm{O}_{4}$ at $70 \mathrm{~F}$, or in both fuels at $160 \mathrm{~F}$. Compatibility was judged by weight and physical change and change in appearance of propellant and lubricant. Among the greases, a completely polymeric perfluorinated material with a fluorocarbon-telomer thickener (5), showed an unsurpassed compatibility with propellants and, in the oxygen-compatibility tests, a remarkable inertness. 
The test results, shown in Table 4, include immersion times, propellants, and descriptions of the change in appearance of the propellant, such as discoloration, gas formation, and lubricant removal or swelling. Discoloration, per se, is not always reason for rejection, however. Propellant discoloration under some of these test conditions is thought to be caused mainly by the combination of normal decamposition of propellants and chemical removal of the adsorbed oxide film from the test-panel surface. This is not uncommon with the $50 \% \mathrm{H}_{2} \mathrm{H}_{4}+50 \%$ UDMH fuel, which is well known for its active solvent and reducing properties.

LUBRICANTS APPROVED FOR USE IN VACUUM

The solid-dry-film lubricants $P, Q, S$, and $U$ (Table I) were approved for use in ultrahigh vacuum, as was the PTFE reinforced-fiber glass-composite dry lubricant designated Z. Greases B and E were also approved after being subjected to a vacuum exposure test under static conditions. This investigation was aimed primarily at the weight-loss characteristics of all these lubricants after a 14-day exposure to a vacuum of $10^{-8}$ torr (or better), at room temperature, and at $300 \mathrm{~F}$. Over 30 different types of Iubricants were screened, 12 of which were of the solid-dry-film-lubricant type. The two greases, the composite, and the four solid-dry-film lubricants mentioned were approved, based upon the results obtained with this static-condition, vacuum-environment screening test program.

Most of the spacecraft parts to be lubricated are made of aluminum, primarily because of weight limitations. These aluminum surfaces are usually protected against corrosion by an anodic conversion coating. A test program was initiated to determine which of the three conventional anodic coatings imparts the best adhesive surface to solid-dry-film lubricants such as $P$ and $S$. These 
two materials were chosen because they consist entirely of inorganic constituents.

Three anodic coatings were investigated: chromic (grey) anodize per MIL-A-8625A, Type I; sulfuric anodize per MII-A-8625A, Type 2, and hard anodize per MII-A-8625A, Type 3. All tests were conducted on the LFW-I Friction-and-Wear test machine ${ }^{3}$ illustrated in Fig. 2. The test conditions included an unidirectional sliding motion at 26 feet per minute, room temperature and atmospheric pressure environment, and a normal load of 630 pounds, resulting in an average bearing pressure of approximately 40,000 psi. Tests were run to a failure point determined by a friction coefficient of 0.175 .

The anodized Timken ring shown in Fig. 2 was made from $2024 \mathrm{~T} 4$ aluminum per Fed. Spec. QQ-A-268, with a surface finish held to 15 microinches rms. The ring was lubricated with a coating thickness between 0.0003 and 0.0005 inches. The unlubricated test block, as illustrated in Fig. 2, was made of the same material and had its bearing area ground to a surface finish of 6-12 microinches rms. The test block was anodized only. The buildup of the chromic and sulfuric-anodic coatings was, in most cases, less than 0.0006 inches, and the hard anodic coating buildup varied from 0.0010 to 0.0015 inches.

The results, graphically shown in Fig. 3, clearly indicate that the sulfuric anodize is the most favorable pretreatment. This explains why this anodize was chosen as the necessary pretreatment for the aluminum specimens of the sliding-friction-in-vacuum test program.

These preliminary investigations were not completely satisfactory for the mechanisms and components used on manned spacecraft. The behavior of

\footnotetext{
${ }^{3}$ Alpha LFW-I Friction-and-Wear test machine, a modified McMillan-type tester, made by Alpha Molykote Corp., Stamford, Conn.
} 
lubricaints in an ultrahigh vacuum environment under dynamic conditions was more pertinent, particularly in connection with molecular or "cold" welding. . In order to prevent "atomically clean" metallic surfaces, caused by the vacuum condition, from being subjected to this phenomenon, these bearing surfaces must be kept separated. Solid-dry-film lubricants appeared to be the most promising solution to this problem, particularly in cases where latches, cams, linkages, rod ends, door hinges, and other sliding surfaces were involved.

A sliding-friction-in-vacuum test program was initiated to study wear-Iife characteristics and frictional coefficients of lubricants. The testing equipment (Fig. 4) consisted of a frame, load strut, load cell, load ring (connected through a pillow block to a variable drive), and friction force pick-up recorder. The sliding motion is oscillatory, with a total stroke of approximately 1.5 inches. The test specimen configuration is shown in Figs. 5 and 6; the surfaces to be lubricated were ground to a 16-microinch-rms surface finish. The test specimens were fabricated from either Rockwell c56-60 electroless nickel-plated maraging steel, 2024T4 aluminum per Fed. Spec. QQ-A-268, or 6Al-4V titanium.

The basic test procedure was as follows:

1. The specimens were installed in the test fixture and continuously cycled at atmospheric pressure under the specified nominal bearing load at a speed of $1 \mathrm{cpm}$ (cycles per minute) for 10 cycles.

2. At 11 cycles, the speed was increased to $10 \mathrm{cpm}$, and cycling was continuous to 100 cycles.

3. At 101 cycles, the cycling was stopped, and the vacuum chamber sealed, baked out, and evacuated to a pressure of at least as low as $5.0 \times 10^{-8}$ torr. Cycling was restarted at $10 \mathrm{cpm}$ and allowed to continue until 500 cycles had 
elapsed. With the high-temperature tests, the bake-out cycle required more than 6 days.

4. From 501 to 2000 cycles, the testing was intermittent, in that cycling occurred for 10 minutes at $10 \mathrm{cpm}$, followed by 50 minutes of static loading. Thus, this test phase lasted for an interval of 15 hours.

5. At 2001 cycles, continuous autamatic cycling at $10 \mathrm{cpm}$ was initiated. Recording of friction force, which had been continuous from the start o: the test, was readjusted to sample 5 cycles every 15 minutes ( 150 cycles) until failure.

Temperature programs were either ambient or alternating, that is, from $-250 \mathrm{~F}$ to $300 \mathrm{~F}$. The vacuum levels in all tests varied from $3.5 \times 10^{-7}$ to $9.0 \times 10^{-10}$ torr. Each test was halted when failure of the solid-dry-film lubricant occurred, as evidenced by either an increase of $100 \%$ above the lowest consistent friction force obtained, or the appearance of erratic behavior in the oscillographic trace of the friction force. The complete results are shown in Table 5, in which friction coefficients, cyclic wear life, and type of failure are summarized. Lubricant $T$ was vacuum-tested but was rejected because of low wear-life.

The custom-built equipment used and the rather severe sliding bearing action involved preclude the comparison of results with those obtained on standard bearing testers currently in use throughout the industry. For this reason, a number of ambient (atmospheric) pressure check-out tests were conducted in an attempt to isolate the effects of an ultrahigh vacuum environment on lubricant behavior.

The wear-life data are, however, indicative of the comparative merits of the lubricants investigated, and the coefficients of friction were, in most vacuum 
tests, Iower than in those tests conducted in ambient pressures. The lower coefficients were most markedly apparent for candidates $P$ and $U$.

Further testing to provide more data is planned. Also, the adoption of a standard substrate material is being considered; this would establish a sounder basis of comparison for other candidate lubricants. DISCUSSION

Many large-scale tests are planned to demonstrate design reliability. These tests will include as many environmental factors as feasible. Flight data will gradually demonstrate the actual performance. The selection of lubricants, as of this date, can be quite arbitrary, since meaningful results applicable to all operating conditions of a combined environment can be demonstrated only by actual flight experience. As hardware is built, the lubricants are obtained and coatings applied.

Subcontractor test programs are largely unsupervised and are generally functional in nature rather than an attempt to expose materials to static conditions. Also, the test environments are usually much less severe, such as use of unrealistic pressure and amission of thermal and radiation inputs. Similarly, a conditioning soak of several days prior to operation is generally avoided. Perhaps the test philosophy becomes one of proving that the design is satisfactory rather than a concerted effort to reveal all weaknesses in the design.

Results of Project Mercury were highly satisfactory, and in the Gemini ProGram only one failure has involved a lubricant. Meanwhile, many contracts are being carried out to examine new lubricants and new environmental combinations. As yet, however, the ideal lubricant appears to be in the distant future. 


\section{ACKNOWLEDGMENTS}

The authors wish to extend their appreciation to E. F. Davies, R. L. Goclowski, W. W. Green, R. L. Wallner, and S. M. Mitchell of the Engineering Development Laboratories of the Space and Information Systems Division of North American Aviation, Inc., for performing all the experimental work and also for their belpful suggestions during the program.

\section{REFERENCES}

1. Anon., "Halocarbon, Chlorofluorocarbon Lubricants," Halocarbon Products Corp., Hackensack, N. J., 1965.

2. Fisch, K. R., Peale, I., Messina, J., and Gisser, H., "Compatibility of Lubricants with Missile Fuels and Oxidizers," ASLE Trans. 5, 287-296 (1962).

3. Messina, J., and Gisser, H., "Grease-Type Lubricants Compatible with Missile Fuels and Oxidizers," USAF Aerospace Fluids and Lubricants Conference, San Antonio, Texas, April 1963.

4. Alsandor, E., "Compatibility-Solubility of Greases with $\mathrm{N}_{2} \mathrm{O}_{4}, \mathrm{~N}_{2} \mathrm{H}_{4}$ and IRFNA," Rocketdyne Report No. MPR 3-252-561, March 1963.

5. Gumprecht, W. H., "PR-143, A New Class of High Temperature Fluids," ASLE Paper No. 65LC-3.

6. Hagan, M. A., and Williams, F. J., "The Development and Testing of a New Ceramic-Bonded Dry Film Lubricant," USAF-SWRI Aerospace Bearing Conference, San Antonio, Texas, March 1964. Published by Southwestern Research Institute, Sept. 1964. 
Table 1

Identification and Description of Lubricants Tested

\begin{tabular}{|c|c|c|}
\hline Code & Lubricant description & Main characteristics \\
\hline \multicolumn{3}{|c|}{ Greases } \\
\hline A & Dimethylsiloxane base with mica powder filler & Good O-ring Iubricant \\
\hline B & $\begin{array}{l}\text { Ester-silicone base grease with unknown thickener } \\
\text { per MII-G-27549 }\end{array}$ & High loads, low speed \\
\hline C & $\begin{array}{l}\text { Perfluorinated base with fluorocarbon-telomer } \\
\text { thickener ( } 5 \text { ) }\end{array}$ & $\begin{array}{l}\text { High temperature, } \\
\text { chemically inert }\end{array}$ \\
\hline D & Silicone base filled with metal oxides & Thermal conductive \\
\hline E & $\begin{array}{l}\text { Methylchlorophenyl silicone with lithium soap } \\
\text { thickener }\end{array}$ & $\begin{array}{l}\text { Wide temperature } \\
\text { range }\end{array}$ \\
\hline$F$ & Chlorofluorocarbon base with silica gel thickener & Inert, good wettability \\
\hline G & $\begin{array}{l}\text { Perfluorotrialkylamine base with fluorocarbon- } \\
\text { telomer thickener (3) }\end{array}$ & $\begin{array}{l}\text { Compatible with fuels } \\
\text { and oxidizers }\end{array}$ \\
\hline H & $\begin{array}{l}\text { Trifluorovinylchloride polymer base with unknown } \\
\text { thickener }\end{array}$ & $\begin{array}{l}\text { Compatible with } \mathrm{H}_{2} \mathrm{O}_{2} \text {, } \\
\mathrm{HNO}_{3} \text {, and most acids }\end{array}$ \\
\hline I & Chlorofluorocarbon base with unknown thickener & Chemically inert \\
\hline $\mathrm{J}$ & Trifluorochloroethylene base with unknown filler & Chemically inert \\
\hline $\mathrm{K}$ & $\begin{array}{l}\text { Trifluoropropylmethylpolysiloxane base with } \\
\text { silica gel filler }\end{array}$ & Chemically inert \\
\hline L & Chlorofluorocarbon with unknown thickener & Very inert to acids \\
\hline M & Dimethylpolysiloxane base with silica filler & Wide temp. range \\
\hline N & $\begin{array}{l}\text { Phenylmethylpolysiloxane base with an organic } \\
\text { ester-type material and a lithium soap filler }\end{array}$ & $\begin{array}{l}\text { Excellent o-ring } \\
\text { lubricant }\end{array}$ \\
\hline 0 & $\begin{array}{l}\text { Fluoroalkylester and fluorinated hydrocarbon } \\
\text { base with fluorocarbon-telomer thickener }\end{array}$ & $\begin{array}{l}\text { Compatible with fuels } \\
\text { and oxidizers }\end{array}$ \\
\hline \multicolumn{3}{|c|}{ Solid-dry-film lubricants } \\
\hline $\mathrm{P}$ & $\begin{array}{l}\text { Inorganic, electrophoretic binder system with } \\
\text { MoS, graphite, and } \mathrm{PbS}\end{array}$ & $\begin{array}{l}\text { Low friction coeffi- } \\
\text { cient, good wear life }\end{array}$ \\
\hline Q & $\begin{array}{l}\text { High density, modified phenolic binder system } \\
\text { with } \mathrm{MoS}_{2}, \mathrm{PbS} \text {, and } \mathrm{Sn}\end{array}$ & $\begin{array}{l}\text { Excellent corrosion } \\
\text { resistance }\end{array}$ \\
\hline $\mathrm{R}$ & $\begin{array}{l}\text { Inorganically bonded } \mathrm{MoS}_{2}, \mathrm{PbS} \text {, and graphite with } \\
\text { an acrylic top-coat sealer }\end{array}$ & $\begin{array}{l}\text { Good wear life, some } \\
\text { corrosion resistance }\end{array}$ \\
\hline$S$ & Sodium silicate binder system with only $\mathrm{NoS}_{2}$ & Average wear life \\
\hline $\mathrm{T}$ & Silicone resin binder system with $\mathrm{MoS}_{2}$ and $\mathrm{Sn}$ & Low vapor pressure \\
\hline $\mathrm{U}$ & Ceramically bonded graphite, MoS, and Ag (6) & Excellent wear life \\
\hline $\mathrm{V}$ & Inorganic binder system with only graphite & Extremely inert \\
\hline W & $\begin{array}{l}\text { Inorganic binder system with graphite, } \mathrm{PbS} \text {, and } \\
\text { a special unknown organic additive }\end{array}$ & $\begin{array}{l}\text { Chemically inert and } \\
\text { good wear life }\end{array}$ \\
\hline \multicolumn{3}{|c|}{ Anti-seize compounds } \\
\hline $\mathrm{X}$ & Aromatic biphenylchloride, mixed with graphite & LOX impact resistant \\
\hline Y & $\begin{array}{l}\text { Graphite powder (24\%) in an organic vehicle plus } \\
\text { a few unknown additives }\end{array}$ & Breathing air systems \\
\hline \multicolumn{3}{|c|}{ Composite dry lubricants } \\
\hline $\mathrm{Z}$ & $\begin{array}{l}\text { Multiple layers of PTFE and glass fibers woven in } \\
\text { cloth-like form, bonded to the bearing surface }\end{array}$ & $\begin{array}{l}\text { Long wear life in } \\
\text { spherical bearing }\end{array}$ \\
\hline
\end{tabular}


Table 2

Lubricant-Oxygen Compatibility Test Results

\begin{tabular}{|c|c|c|c|c|c|c|c|c|c|}
\hline \multirow[b]{2}{*}{$\begin{array}{l}\text { Lubri- } \\
\text { cant }\end{array}$} & \multirow{2}{*}{$\begin{array}{l}\text { Sample } \\
\text { weight } \\
\text { loss (\%) }\end{array}$} & \multicolumn{4}{|c|}{ Outgassing products (ppm) } & \multirow{2}{*}{$\begin{array}{l}\text { Con- } \\
\text { den- } \\
\text { sate }\end{array}$} & \multirow{2}{*}{\multicolumn{3}{|c|}{$\begin{array}{c}\text { Odor rating } \\
\text { and } b \\
\text { status }\end{array}$}} \\
\hline & & CO & $\mathrm{CO}_{2}$ & $\mathrm{H}_{2} \mathrm{O}$ & $\frac{\text { Total }}{\text { organics }}$ & & & & \\
\hline$P$ & 0.963 & - & - & 6.35 & 82.5 & No & 2 & -- & A \\
\hline$Q$ & 1.108 & 49 & - & 5.35 & 53.0 & No & 1 & -- & A \\
\hline $\mathrm{R}$ & 2.507 & - & - & 11.54 & 11.0 & No & 1 & -- & A \\
\hline $\mathrm{z}$ & 0.162 & - & 99 & 1.552 & 10.0 & No & I & -- & A \\
\hline A & 0.093 & - & - & 345.2 & 30.0 & Yes & I & -- & A \\
\hline B & 0.083 & 1 & 13 & 399.2 & 53.1 & No & $I$ & -- & A \\
\hline $\mathrm{C}$ & 0.013 & - & - & 29.1 & 4.1 & No & $I$ & -- & A \\
\hline D & 0.038 & 34 & - & 99.0 & 6.2 & No & 1 & -- & A \\
\hline $\mathbf{E}$ & 0.568 & - & - & 133.3 & 9.1 & Yes & 2 & -- & $\mathrm{R}$ \\
\hline$F$ & 5.528 & - & - & 380.1 & 1004.3 & Yes & - 1 & -- & $\mathrm{R}$ \\
\hline G & 56.82 & - & - & - & 9.6 & Yes & $I$ & -- & $\mathrm{R}$ \\
\hline $\mathrm{H}$ & 0.298 & - & 13 & 108.1 & 271.2 & Yes & 2 & -- & $\mathrm{R}$ \\
\hline $\mathrm{x}$ & - & - & - & - & 2.1 & No & 3 & -- & $\mathrm{R}$ \\
\hline$Y$ & 4.053 & 49 & - & 530.2 & 29.3 & Yes & 3 & -- & $\mathrm{R}$ \\
\hline
\end{tabular}

Detectable $=1$; objectionable $=2$; irritating $=3$.

$\mathrm{b}_{\text {Approved }}=\mathrm{A}$; rejected $=\mathrm{R}$. 
Table 3

Lubricant Compatibility Test Results with $\mathrm{N}_{2} \mathrm{O}_{4}$ and $\mathrm{N}_{2} \mathrm{H}_{4}$

\begin{tabular}{|c|c|c|c|c|c|c|}
\hline \multirow{3}{*}{$\begin{array}{l}\text { Lubri- } \\
\text { cant }\end{array}$} & \multicolumn{3}{|c|}{$\mathrm{N}_{2} \mathrm{O}_{4}$ oxidizer } & \multicolumn{3}{|c|}{$\mathrm{N}_{2} \mathrm{H}_{4}$ propellant } \\
\hline & \multicolumn{2}{|c|}{$\begin{array}{l}\text { Solubility } \\
\text { rate }(\%)\end{array}$} & \multirow{2}{*}{$\begin{array}{c}\text { General } \\
\text { observations }\end{array}$} & \multicolumn{2}{|c|}{$\begin{array}{l}\text { Solubility } \\
\text { rate }(\%)\end{array}$} & \multirow{2}{*}{$\begin{array}{c}\text { General } \\
\text { observations }\end{array}$} \\
\hline & Iiquid & Vapor & & $\overline{\text { Liquid }}$ & Vapor & \\
\hline$I$ & 100 & 100 & $\begin{array}{l}\text { Reactive, turned } \\
\text { white, very soluble }\end{array}$ & 99 & 64 & $\begin{array}{l}\text { Reactive, turned } \\
\text { brown }\end{array}$ \\
\hline $\mathrm{J}$ & 100 & 98 & $\begin{array}{l}\text { Reactive, turned } \\
\text { white, washed away }\end{array}$ & 98 & 18 & $\begin{array}{l}\text { Reactive, turned } \\
\text { dark brown }\end{array}$ \\
\hline $\mathrm{K}$ & 98 & 40 & $\begin{array}{l}\text { Reactive, turned } \\
\text { light yellow, residue }\end{array}$ & $<1$ & $<1$ & $\begin{array}{l}\text { Slight discolora- } \\
\text { tion, no reaction }\end{array}$ \\
\hline $\mathrm{X}$ & 100 & 100 & Soluble, no reaction & 93 & 95 & $\begin{array}{l}\text { Soluble, washed } \\
\text { away, no reaction }\end{array}$ \\
\hline $\mathrm{I}$ & 57 & & $\begin{array}{l}\text { Soluble, turned brown } \\
\text { hard residue }\end{array}$ & 4 & $<1$ & $\begin{array}{l}\text { Low solubility, } \\
\text { no reaction }\end{array}$ \\
\hline M & 66 & 94 & $\begin{array}{l}\text { Turned yellow-brown, } \\
\text { residue }\end{array}$ & $<1$ & $<1$ & $\begin{array}{l}\text { Discoloration, } \\
\mathrm{N}_{2} \mathrm{H}_{4} \text { absorption }\end{array}$ \\
\hline $\mathbf{N}$ & 96 & 83 & $\begin{array}{l}\text { Turned black, washed } \\
\text { away }\end{array}$ & 13 & $<1$ & $\begin{array}{l}\text { Turned yellow, } \\
\text { grease softened }\end{array}$ \\
\hline
\end{tabular}


Table 4

Lubricant-Propellant Compatibility Test Results

\begin{tabular}{|c|c|c|c|}
\hline $\begin{array}{l}\text { Lubri- } \\
\text { cant }\end{array}$ & $\begin{array}{l}\text { Immer- } \\
\text { sion } \\
\text { time } \\
\text { (days) }\end{array}$ & $\begin{array}{l}\text { Propel- } \\
\text { lant }\end{array}$ & General observations and status ${ }^{a}$ \\
\hline \multirow[t]{3}{*}{ G } & 21 & $A-50^{b}$ & $\begin{array}{l}\text { Slight discoloration of propellant. Grease film swelled. } \\
\text { Weight change of } 6.1 \% \text {. Lubricity maintained. }\end{array}$ \\
\hline & 21 & $\mathrm{MMH}^{\mathrm{b}}$ & $\begin{array}{l}\text { Slight discoloration of propellant. Grease film slight- } \\
\text { ly swelled. Lubricity maintained. No weight change. A }\end{array}$ \\
\hline & 21 & $\mathrm{~N}_{2} \mathrm{O}_{4}^{\mathrm{b}}$ & $\begin{array}{l}\text { Grease film removed. Weight change of } 93.5 \% \text {; however, } \\
\text { white flakg residue on test-tube bottom. } \mathrm{N} O \mathrm{O} \text {, intact. A }\end{array}$ \\
\hline \multirow[t]{3}{*}{ C } & 30 & $A-50$ & $\begin{array}{lr}\text { Very slight swelling. No residue. No weight change } & \text { No } \\
\text { discoloration of propellant. Lubricity maintained. }\end{array}$ \\
\hline & 180 & $A-50$ & $\begin{array}{l}\text { No residue. No weight change. No propellant discolora- } \\
\text { tion. Grease film not visibly affected. }\end{array}$ \\
\hline & 30 & $\mathrm{~N}_{2} \mathrm{O}_{4}$ & $\begin{array}{l}\text { Very slight solubility. Very small amount of residue on } \\
\text { test-tube bottom. Grease film not visibly affected. A }\end{array}$ \\
\hline \multirow[t]{2}{*}{0} & 30 & $A-50$ & $\begin{array}{l}\text { Grease film removed; however, white flaky residue on } \\
\text { test-tube bottom. No propellant discoloration. }\end{array}$ \\
\hline & 30 & $\mathrm{~N}_{2} \mathrm{O}_{4}$ & $\begin{array}{l}\text { Excessive flaky residue on test-tube bottom and on the } \\
\text { panels. Also hard, dry, white powder. No weight } \\
\text { change. }\end{array}$ \\
\hline \multirow[t]{2}{*}{$\mathrm{K}$} & 30 & MMH & $\begin{array}{l}\text { Grease film not visibly affected. No propellant discol- } \\
\text { oration. No residue. No weight change. }\end{array}$ \\
\hline & 30 & $\mathrm{~N}_{2} \mathrm{O}_{4}$ & $\begin{array}{l}\text { Test terminated, because base oil completely dissolved } \\
\text { after } 12 \text { days. White gel residue. } \mathrm{N}_{2} \mathrm{O}_{4} \text { intact. }\end{array}$ \\
\hline \multirow[t]{2}{*}{$\mathbf{P}$} & 21 & $A-50$ & $\begin{array}{l}\text { Propellant discoloration. Slight gas build-up in test } \\
\text { tube. Lubricant film had soft spots; easily removed. }\end{array}$ \\
\hline & 21 & $\mathrm{MMH}$ & $\begin{array}{l}\text { Strong propellant discoloration; dark amber. Large } \\
\text { amount of black particle residue. Some weight change. } \underline{R}\end{array}$ \\
\hline \multirow[t]{3}{*}{$v^{c}$} & 21 & $A-50$ & $\begin{array}{l}\text { Propellant discoloration. No residue. No weight change. } \\
\text { Lubricant film in good condition. }\end{array}$ \\
\hline & 21 & MMH & $\begin{array}{l}\text { Slight propellant discoloration. No residue. No weight } \\
\text { change. Lubricant film in good condition. }\end{array}$ \\
\hline & 21 & $\mathrm{~N}_{2} \mathrm{O}_{4}$ & $\begin{array}{l}\text { No change in oxidizer. No residue. Some weight change. } \\
\text { Iubricant film in good condition. }\end{array}$ \\
\hline \multirow[t]{5}{*}{ W } & $\begin{array}{l}8 \\
8\end{array}$ & $A-50$ & No propellant discoloration. Lubricant unchanged. $\bar{A}$ \\
\hline & 8 & $\mathrm{~N}_{2} \mathrm{O}_{4}$ & $\begin{array}{l}\text { Same as above, no change at all. } \\
\text { Same as above, no change at all. }\end{array}$ \\
\hline & 21 & $A \leq 50$ & $\begin{array}{l}\text { Propellant unchanged. Lubricant film somewhat duller. } \\
\text { No residue on test-tube bottom; some at meniscus } \\
\text { level. }\end{array}$ \\
\hline & 21 & $\mathrm{MMH}$ & $\begin{array}{l}\text { No propellant discoloration. No residue. Lubricant film } \\
\text { completely intact and not softened. }\end{array}$ \\
\hline & 21 & $\mathrm{~N}_{2} \mathrm{O}_{4}$ & Same as above, no change at all. \\
\hline & & & , under \\
\hline
\end{tabular}


Table 5

Sliding-Friction-in-Vacuum Test Results

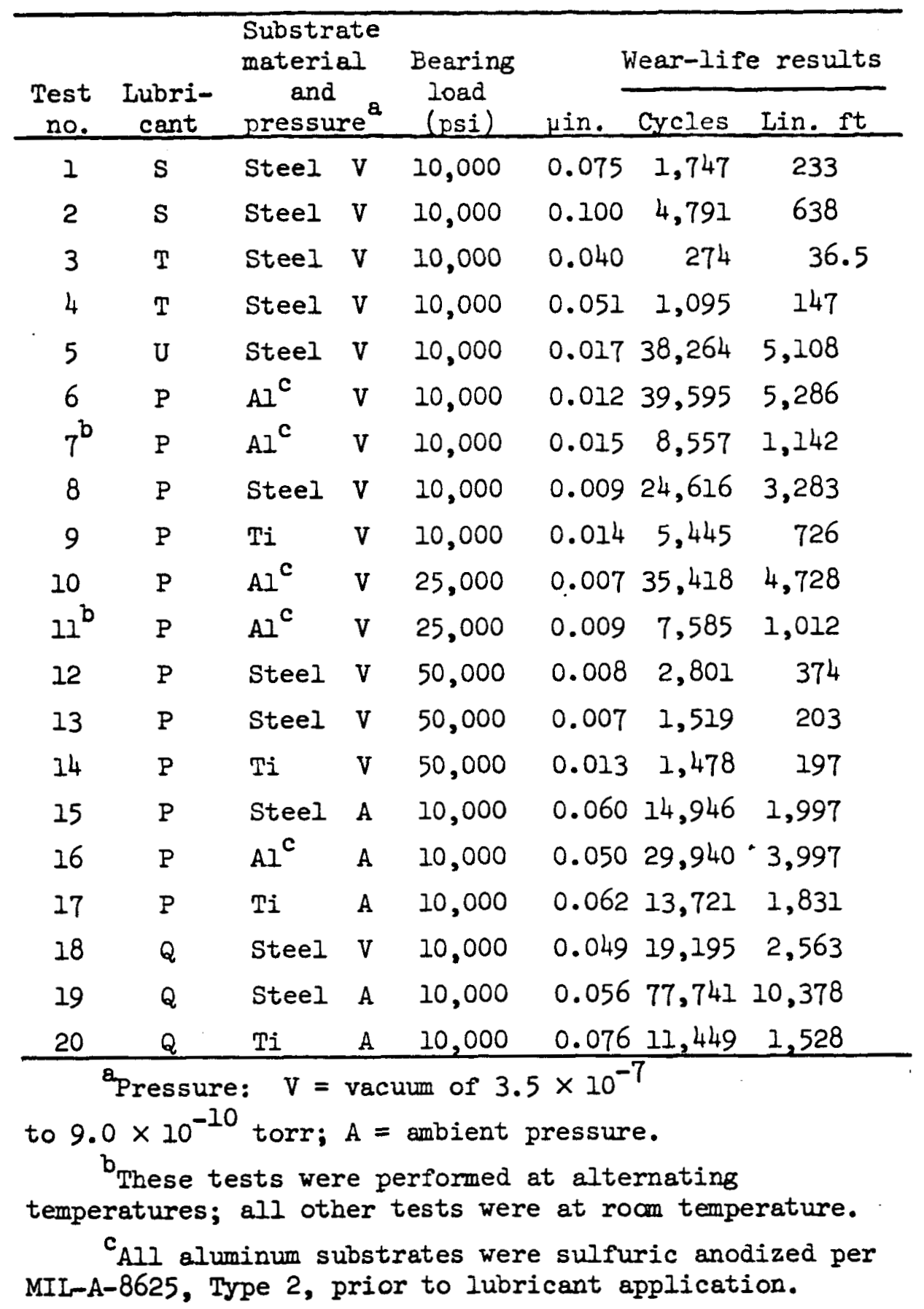




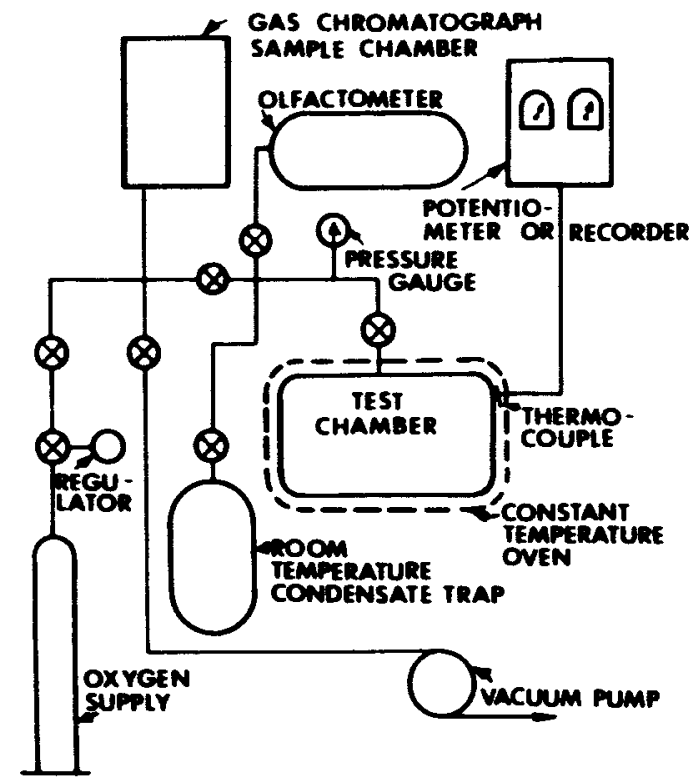

FIG. I LUBRICANT OX YGEN OUTGASSING TEST EOUIPMENT SCMEMATIC

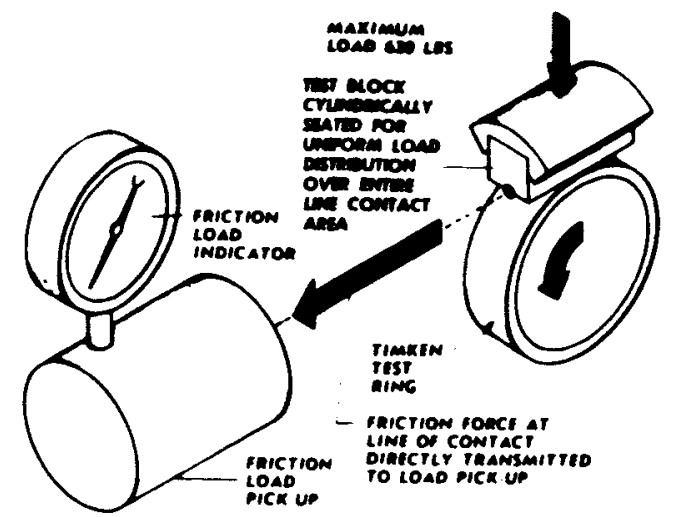

FIGURE 2

Modei LFW. I Lubricant-Frition: Wear Testrig Ma hine

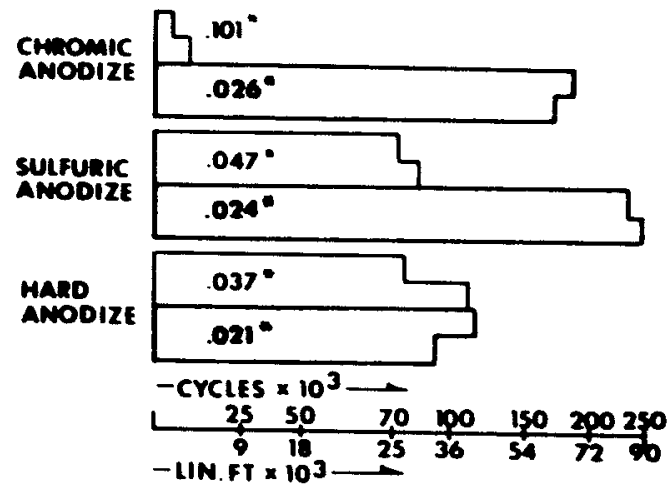

- $\mu_{k}$ - Average KINetic coefficient OF FRICTION VALUE

$\square$ CAmoIDates $\square$ Canoidaie -

FIG. 3 SOLID DRY FILM IUARICANT-ANODK CONIMK COMPATIALITY TEST RESULTS. EACH QN REPESENTS TWO IEST RUNS ON LFWH TESTER. 

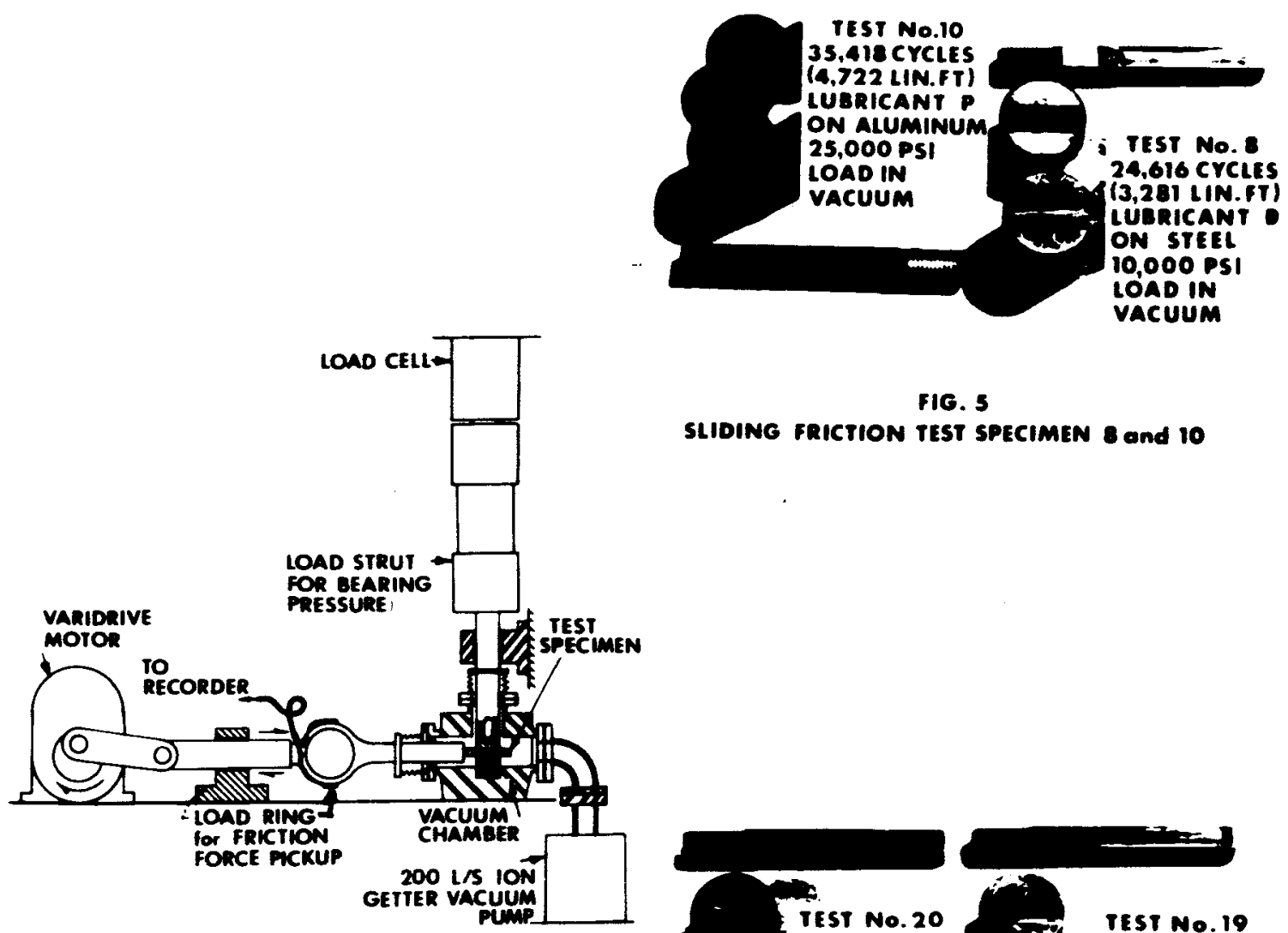

FIG. 5

SLIDING FRICTION TEST SPECIMEN 8 and 10

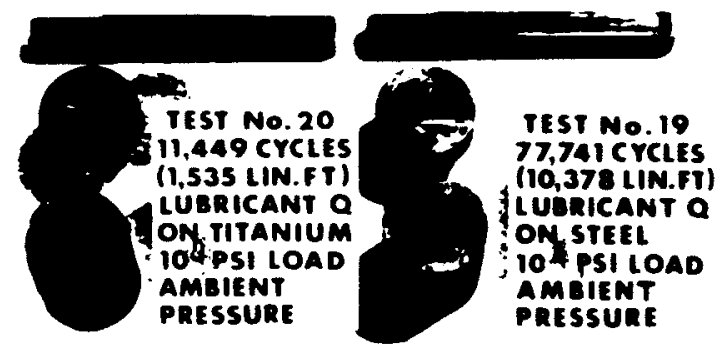

F16. 6

SLIDING FRICTION TEST SPECIMEN 19 and 20 